\title{
The Changing of the Gods: Religion, Religious Transformation and the Indian Immigrant Experience
}

\author{
Thomas W. Segady ${ }^{1}$, Swati Shirwadkar ${ }^{2}$ \\ ${ }^{1}$ Stephen F. Austin State University, Nacogdoches, USA \\ ${ }^{2}$ Institute of Public Law, University of Tartu, Tartu, Estonia \\ Email: tsegady@sfasu.edu, shirwadkar.swati@unipune.er.net
}

Received June 29 ${ }^{\text {th }}$, 2012; revised July 28 ${ }^{\text {th }}, 2012$; accepted August $16^{\text {th }}, 2012$

\begin{abstract}
The Durkheimian notion that there is a close correspondence between the type of religion within a society and the structure of the society itself is now taken to be nearly axiomatic. As societies become increasingly dynamic and fragmented, however, the nexus between religion and society becomes far more complex. With globalization and widespread movements of populations struggling to maintain their identities within the contexts of both the old and new societies, changes of religion-including religious affiliation and religiosity-are inevitable. Cultural and social aspects of these changes are explored with reference to Indians migrating to the United States.
\end{abstract}

Keywords: Immigration; Identity Construction; Religiosity; Religious Affiliation

\section{Introduction}

In his now-classic work, The Elementary Forms of Religious Life, Durkheim staked out epistemological territory that sociologists have taken as axiomatic since that time. For example, In a debate with the "apriorism"1 of Kant, there are categories of experience and reason that are universal. Thus, certain cultural elements would also be universal. They are "facts in common" that are inherited by all humans, as a consequence of the common structure of consciousness. This position, according to Durkheim, possesses the distinct advantage of avoiding the possibility for the dissolution of all categories of experience and understanding into a purely relativistic form of empiricism; for example, that of Hume.

\section{Durkheim's Critique of Hume's Skepticism}

The debate between Kantian “apriorism” and Hume's empirical-based skepticism was one in which Durkheim was fully prepared to engage and use as a foil for establishing a unique sociological perspective. Against Hume, Durkheim stated his position: “... to reduce reason to experience is to conjure it [reason] away, for the universality and necessity that characterize it are reduced to pure appearance... all objective reality is removed from the logical life which these categories function to regulate and organize. Classical empiricism verges on irrationalism, and perhaps it should be labeled as such" (Durkheim, 2001: p. 16). One might surmise from this that Durkheim would align his argument with the neo-Kantians, although not in the same manner that Weber had done earlier in his famous essays based in part on the work of Heinrich Rickert, first pub-

\footnotetext{
${ }^{1}$ This is the term that Durkheim ascribed to those who argued the Kantian position.

${ }^{2}$ Much of Weber's neo-Kantian perspective was based on correspondence with Rickert. See, for example, Weber's The Methodology of the Social Sciences (trans. Shils Edward Shils and Henry Finch, 1949).

${ }^{3}$ i.e., the "difficulties" inherent in both classical empiricism and classical apriorism.
}

lished in $1904^{2}$. However, Durkheim's approach is far more nuanced, as is seen in his characterization of what he terms the "apriorists". Durkheim praises those who adhere to this position for not denying the role of logic and the necessity of some form of organized perceptions - they cannot be merely randomly acquired or expressed. But from where does this necessary logic or organization come? It is here, Durkheim asserts, that the "apriorists" overreach: as "rationalists", they "believe the world has a logical aspect that reason eminently expresses. To do this, however, they must attribute to the mind a certain power of transcending experience and adding to what is immediately given; but they neither explain nor justify this singular power" (Durkheim, 2001: p. 16). Thus, the empiricists have experience without order or system; "apriorists" have order and system but cannot explain the unique nature of experience. Further, they have somehow "transcended" the need to explain the source of the objectivity that they posit exists.

That Durkheim engaged in this argument early in the Elementary Forms demonstrates that he was still intent on establishing a rationale for a unique methodology for the social sciences, even though this was nearly the last of his works. He had addressed the need for a unique methodology in The Rules of Sociological Method, written over fifteen years earlier. Moreover, Durkheim was using this classic debate between the positions of the Kantian a priori versus the skepticism of Humean empiricism as a point of departure for outlining his own conception of the relation of society to religion, and of the relation of religion to the individual. The foundation for this conception is stated in his introductory essay to The Elementary Forms: “... if we accept the social [italics added] origin of categories, a new perspective becomes possible that should help us to avoid these contrary difficulties”3 (Durkheim, 2001: p. 17). Society thus exists sui generis, and is irreducible to any collection of individual experiences or beliefs. "Society has its own features which are not found, or not found in the same form, in the rest of the world" (Durkheim, 2001: p. 18). Society exists independently of the individual, but also exists subjectively and 
internally, in the sense that these experiences and beliefs are shaped by the society. By inference, even for the individual to think about the society is mediated, to a high degree, by the society itself. This nexus is more than universal for Durkheim. It is unequivocally necessary.

This approach, Durkheim claims, "preserves all the essential principles of apriorism but is inspired by that spirit of positivism which [Humean] empiricism tried to satisfy" (Durkheim, 2001: p. 21). In a very real sense, individuals as humans and the society in which they live are separate and distinct, but began the process of their differentiation simultaneously. Only when a shared sense of morality emerged could individuals become fully human, distinguishing themselves from other forms of life. But in this instant, the source of morality itself became externalized and was thus "set apart" from any one person who shared this nascent social order. It became, Durkheim asserted, "transcendental” (in the respect of being "set apart") and independent of the person. The first community was thus a moral community that gradually formed rituals and rites to reinforce, protect and celebrate new social forces that existed externally to any one individual in the group. In fact, Durkheim referred specifically to these emergent societies as forces that were not only "real", but possessed the capacity to shape the realities of the persons in them: "When I speak of these principles as forces, I do not use the word in a metaphorical sense; they behave like real forces... they are even physical forces... and in addition to their physical nature, they have a moral nature" (Durkheim, 2002: p. 192).

\section{The AnneeSociologique and the Durkheimian Perspective}

In a series of essays with Marcel Mauss (1901-1902), Durkheim states this relationship between individuals and the external entity they have constructed most succinctly: "Now the classification of things reproduces this classification of men" (italics in original) (Durkheim \& Mauss, 1963: p. 10). This is a powerful statement, and it captures exactly the knowledge that Durkheim believed could only be obtained through the investigation of a small band of "primitive" peoples who expressed only the fundamentals of belief. This classic statement implies a very dynamic nature of society posited by Durkheim and his colleagues (including Mauss) within the AnneeSociologique 4 . The externalization of the moral beliefs of more "complex" societies is, in principle, understandable in much the same way. Cladis, in his introductory essay to the 2001 translation of The Elementary Forms, provides an illustration that could have been instantly recognized by Durkheim himself or, still later, anticipated Bellah's (1975) notion of civil religion:

“... imagine this: a fellow citizen—a French Jew named Dreyfus-is unjustly accused and convicted of high trea-

\footnotetext{
${ }^{4}$ The Annee, according to Coser (1977), was a closely-knit intellectual community, unlike the neo-Kantian group with which Weber is associated. ${ }^{5}$ See, for example, Khaldun's writings in translation by Duncan R. MacDonald, A Selection from the Prolegomena of the IbnKhaldun. (Leiden: E. J Brill, 1950).

${ }^{6}$ Parsons, for example, states that: "Durkheim opened up an entirely new line of thought by suggesting that... [there] was in fact no common intrinsic quality of things treated as sacred which could account for the attitude of respect. In fact, almost everything from the sublime to the ridiculous has in some society been treated as sacred... At this point, Durkheim became aware of the fundamental significance of his previous insight that the attitude of respect for sacred things was essentially identical with the attitude for moral authority (Parsons, 1949: pp. 52-66).
}

son. It is clear to you and others that he has been scapegoated by military and government officials: his rights have been betrayed. Soon, many rally to his defence. With marches in the street and flags and speeches in the air, your society is stirred and the social ideals of liberty and justice are renewed. You witness a moral community being forged: sacred rites and beliefs clearly emerge... You begin to realize that the elementary forms of religious life permeate not only traditional but modern societies as well (Cladis, 2001: p. vii).

The ethnographic evidence marshaled by Durkheim and Mauss - and the interpretation of that material-has undergone severe criticism since the publication of essaysof 1912 (Needham, 1963). Perhaps the most forceful was the remark by Evans-Pritchard (1960: p. 99) that: "It was Durkheim, and not the savage, who made society into a god.” Most certainly, the ideas expressed in this and later works are not entirely new or unique. For example, IbnKhaldun, writing in the fourteenth century, asserted that in large, sedentary societies, religion would emerge as the primary basis for social solidarity, superseding in importance even the state ${ }^{5}$. And yet, the contribution of the idea that religion forms the basis not only of social solidarity, but of individual identity, was seminal ${ }^{6}$. Durkheim, even as late as the publication of The Elementary Forms, did not intend to investigate in any systematic fashion the dynamics of change inherent in the society or the attendant shifts in religion-his was a consideration of the formation of society, and much less of the dynamics of the society itself. Later studies-for example, the classic survey of primitive religion by Lowie (1924) —-took the same approach, and Goode's (1951) functional analysis was heavily influenced by Durkheim's approach.

The first empirically-grounded attempt to extend Durkheim's theory to the social dynamics of change and modernization came with Swanson's signal work, The Birth of the Gods (1960). At the outset, Swanson identifies the "elementary forms" of religion he will investigate:

We shall ask about the experiences from which seven ideas might originate: the conceptions of a monotheistic deity, of polytheistic gods, of ancestral spirits, reincarnation, the immanence of the soul, the prevalence of witchcraft, and the notion of gods who concern themselves with human moral problems (Swanson, 1960: p. 2).

While conceding that these "ideas" lack complete precision and may in fact be overlapping in some respects, his general purpose converges with that of Durkheim. In an elegant passage, Swanson states: “... behind natural events lies the supernatural-a realm of potentialities and purposes of which natural events are but concretions or expressions even as human behaviors or artifacts are expressions of the potentialities and purposes held by the men who express them" (Swanson, 1960: p. 8). Thus - to retain Durkheim's language - the invisible sacred becomes manifest in the highly observable activities of daily life. And even though these activities might not be viewed by their practitioners as "sacred" in some fashion, having been incorporated into the natural attitude that constitutes their perceptions, values, intentions, and actions, the true foundations of these lie in that invisible realm.

\section{Religiosity and Social Dynamics}

However seminal this insight, it begs several questions re- 
lated to the nature of social change. Echoing the static, Durkheimian view, religion is by definition a culturally conservative force, reinforcing and in fact celebrating existing traditions. The gods are the transcendent representatives of these traditions In Swanson's argument there is the additional implicit assumption that a given social order is seen as natural and the gods who embody that order possess distinct, well-defined qualities: “... insofar as a group has sovereignty, it is likely to provide the conditions from which a concept of spirit originates. The purposes of sovereign groups, like their special sphere of influence [and hence, their representative gods], tend to be distinctive and clear" Swanson, 1960: p. 21). ${ }^{7}$ The ancient Hindu god Indra serves as one example. First identified in the oldest Veda, the Rig Veda (perhaps as ancient as 1450 B. C. E.-cf. Witzel, 2005), Indra was the god who led the invading Aryas into battle over the non-Aryan population of the Punjab (Dandekar, 1997), surpassing even Vishnu and Shiva in importance. He was, in fact, the leader of the Hindu pantheon of gods. For believers, he was seen as the creator of the world and the god of fertility, and was credited with having battled the powerful demon Vritra. He exemplified, in Swanson's conceptual framework, a "superior god" who is at once "more abstract' in the respect that they “... affect the lives of all men engaged in activities relevant to the gods' interests in all times and places” (Swanson, 1960: p. 83).

But how can such a "superior god"- the "King of the Gods" (Cutler, 2003) lose his power, lose his exalted place in the pantheon of gods, or even become forgotten altogether? Much of this has been the fate of the unfortunate Indra. One clue to the decline, if not the demise, of Indra is found in the epic Ramayana. In the early books of the Ramayana, the exceptional qualities and high position of the great warrior Rama himself are compared to Indra - the great upholder of dharma ${ }^{8}$ (Brockington, 2003). By the sixth book of the Ramayana, however, Indra's decline is reflected in the shift from Rama's comparison from Indra to the comparison with Vishnu, who remains to this day at the apex of the pantheon of Hindu gods, together with Shiva and Brahma.

From the perspective of the relationship between religion and society posited by Durkheim, this change in the status of Indra is quite predictable. The explanation (and even more importantly, the prediction) for the changes in religion parallel the changes that occur in society. The shift in identification with the mythic figure of Rama with Vishnu could reflect a trend in ancient Hindu society away from war and conflict to one of preservation, which is the province of Vishnu. Other authors, however, have offered alternative interpretations. Ganeri, for example, argues that Indra expressed powers of reason that could jeopardize the growing hegemony of the Brahmin caste in India. Obedience to religiously-based authority becomes paramount. He provides as evidence an episode in the $M a$ harashtra, in which Indra appears as a jackal and relates this story about his transformation:

I used to be scholarly, a reasoner, a scorner of the Veda.

\footnotetext{
7»Nonsovereign” groups, according to Swanson, may possess a sense of the "spirit" that is less well defined, reflecting the instability of their own social order.

8,'Dharma", while possessing several subtle shades of meaning, might be most generally conceived as being the performance of sacred duty.

9"Nomoi”, for Berger, refer to the ordered meanings that individuals create engendering norms, habits, and a personal Weltanshauung (cf. Kurtz, Lester 2007. Gods in the Global Village, 2nd ed. Thousand Oaks, CA: Pine Forge Press.
}

I was pointlessly fond of critical inquiry and the science of argument. I used to make declarations on the basis of logic: in assemblies, speaking with reasons, I harangued the Brahmins and was rude during the Vedic recitations. I was an unbeliever, skeptical about everything, and though stupid, I thought myself wise. The status of a jackal that I have obtained is the result (Ganeri, 2005: p. 411).

Thus, there is no true "invisible reflection" in this account: The transcendent power of religion is directly invoked by the immanent power of the religious in this world to reinforce personal and group status and security. It is an ironic reversal of the adage: "Whom the gods would destroy, they first make ridiculous." Here, it is a god-and the former "king" of the gods - who is made to look ridiculous. Moreover, it points to a dimension that Durkheimiam theory largely fails to explore: As religion and society become more complex, and as individual and group power can become manifestations or reflections not of other-worldly forces but can be consciously manipulated and reinforced for advantage, the religious is dominated by the socially and politically dominant. This is, of course, much closer to the Marxian position than the Durkheimian, and this does not refer to fully industrialized, Western societies alone. In the case of Hinduism, Waghorne (2004),- - taking a neo-Marxian approach-likens the transformation of goddess temples in Chennai to the sort of "bourgeoisification" of the museum; a celebration of culturally-embedded institutions at the expense of the formerly sacred: ... such public institutions [i.e., museums]...also form the middle class [and] give a clue to the goddess temples in Chennai as sites that may validate the middle class as a rising group (Waghorne, 2004: p. 146). Religion from this perspective becomes a mechanism for legitimating and sustaining power, and if personal identity is at issue, then the identity derived from religion is inherently conservative (in the sense of reinforcing existing social institutions), this-worldly, alienating, and productive of false consciousness.

However, this position does not seem to capture the full range of religion, which has historically been an agent of social change and even revolution, as well as constituting a force for social repression and strictly-enforced maintenance of tradition (Armstrong, 2004). Religion remains a powerful force, both in more traditional and modernized societies. The fact that there are various levels (personal and societal) and functions of religion is articulated by Berger (1967), who recounts the forms legitimation has taken historically in China, Greece, Israel, and Rome, and concludes:

“... the historically crucial part of religion in the process of legitimation is explicable in terms of the unique capacity of religion to 'locate' human phenomena within a cosmic frame of reference. All legitimation serves to maintain reality-reality, that is, defined in a particular human collectivity. The inheritantly precarious and transitory constructions of human activity are thus given the semblance of ultimate security and permanence... the humanly constructed nomoi are given a cosmic status" (Berger, 1967: pp. 35-36) ${ }^{9}$.

While echoing the theme of Durkheim's work that religion serves both to shape and legitimate social reality, there is also a significant shift in emphasis toward religious belief and individual identity. In Berger's account, it is not so much the tension and symbiotic relationship of society and religion that is 
important, as the role that religion plays in the lives of persons in the society. Berger constructs a three-part process of internalization, integrating the social and the personal. The first, externalization, refers to the continually production of human activity, which become tangible in material form as various as tools, weapons, art and literature, or in cultural form such as myths and social networks (Griswold, 1994). This notion, adumbrated by Durkheim, begins to take on individual expression in the next stage, objectivation, as the forms, once produced, begin to take on the cast of an external reality that is recognizeable (and expected) the individual. This again has much in common with the established Durkheimian theme. The difference in theoretical emphasis occurs in Berger's final stage of internalization, in which the objectified "reality" becomes fully internalized. The individual then becomes the focal point for the production of social reality, which is reproduced subjectively but experienced objectively.

Berger illustrates this operating in the central belief of dharma operating in Hinduism: "the violation of [one's individual] dharma is not just a moral outrage against society, but an outrage against the ultimate order that embraces both gods and men and, indeed, all beings" (Berger, 1967: p. 40). That this perspective is still fundamentally Durkheimian is demonstrated in Berger's contention that the individual who rejects or is somehow cut off from religion faces the prospect of the loss of the "nomos" and resulting state of anomie (Berger, 1967: p. 50). In traditional societies, in which religion was either the undisputable dominant or even constituted the single dimension of social life, separation from religion was tantamount to separation for the community.

With increasing differentiation and complexity, there is no overarching "social canopy", as Berger's metaphor suggests. Identity may be captured and expressed in any number of institutions, organizations, and groups apart from religion. From at least the 1960s, sociologists were proclaiming an inevitable trend toward secularization. As Harvey Cox, author of The Secular City proclaimed:

The world looks less and less to religious rules and rituals for its morality or its meanings. For some, religion provides a hobby, for others a mark of national identification, for still others an aesthetic delight. For few and fewer does it provide an inclusive and commanding system of personal and cosmic values and explanations (Cox, 1971: p. 3).

Oddly, however, the inevitable secularization trends predicted from at least this time onward have not occurred, even in the United States, arguably the most highly differentiated, postindustrial society (Gorski, 2000; Stark \& Finke, 2000; Hout \& Fischer, 2002; Sax et al., 2004). Individual identity still finds

\footnotetext{
${ }^{10}$ Wuthnow (1998) suggests that there has been a movement away from religious "dwelling", or practicing religion in established spaces (e.g., church, synagogue, mosque or temple), to religion "seeking", which leads the person on a religious quest that includes more private practice of belief and even ritual.

${ }^{11}$ MacKenzie (1994: p. 102) writes that: "The history of Hinduism is the history of a continual struggle between the devotees of folk religion and the expounders of Forest Books produced by the speculative sages who, in their quest for truth, used primitive myths to illustrate profound doctrinal teachings.”

12 "Bhakti” may be defined as the emphasis on devotion and love of God, as opposed to "jnana", which is an emphasis on wisdom or knowledge as a path to understanding the nature of God.
}

expression in religion and, as Wuthnow (1998) suggests, the trend toward secularization may have been misunderstood by sociologists, as the forms which religion now take often differ significantly from those taken by earlier established (and easily identifiable) denominations ${ }^{10}$.

As a result of these recent investigations, several preliminary conclusions obtain: 1) the general Durkheimian model still retains theoretical power in explaining the emergence and social significance of religion; 2) religion, as society becomes more differentiated and complex, also becomes increasingly differentiated; 3) religion as practiced by individuals takes on differing forms that are increasingly difficult to identify or categorize; and 4) these new expressions of religion, in tandem with more established forms, retain significant influence in shaping individual identity in differentiated, complex societies.

But perhaps neither "society" nor "religion" can remain the fundamental units of analysis. With respect to religion-a highly transportable belief system that crosses national borders with its believers, globalization has increasingly rendered "society" to the status of analytical artifact. Thus, new questions arise regarding the "transnational" character of religion, with the accompany tranformations this change effects in the lives of individuals. To what extent does the person come into a new, globalized locale (but one that is "dis-locating" in terms of identity), with a specific religious perspective, and how does that perspective work to shape his or her self in a new social milieu, and what, in turn, are the reciprocal effects of the new milieu on religious identity over time? And even religion in the sense of "religious affiliation" cannot be conceptualized in the same manner as previously-it too has become less meaningful as an analytic category. A recent (2008) study of American religiosity by the Pew Forum on Religion and Public Life, for example, finds 25\% of American Adults have left their original faith, and that if movement between Protestant denominations is included, $44 \%$ have changed their religious affiliation at least once. Further, the number of native-born Catholics has declined most sharply, and the Pew report concludes that "roughly ten percent of all Americans are former Catholics." Moreover, while the Pew Report finds that if those who claimed "no affiliation" were counted as a religious group, this group would be the fourth most populous in the United States. The Pew report also cautions that this decline does not necessarily correlate with a decline in religiosity, and that "private religion" may reflect the added dimension of privatized "seeking" over public "dwelling” that over.

In asking these questions of Hinduism, one is instantly confronted with the same truism that applies to any analysis of Indian culture: That to describe any one aspect is to call into being its contradiction. However, it might be safely posited at the outset that Hinduism possesses qualities that are highly syncretic (Fellows, 1998) ${ }^{11}$. Babb (1986: p. 1) remarks that: “... the Hindu religious imagination... is expressed as the Hindu tradition's ability to generate multiple and various interpretations within a common frame of reference. It is not static but endlessly protean and full of creative possibilities." In turn, this syncretism has produced, despite the perceived conception of Hinduism as insular and traditional, structures and beliefs that facilitate change and productive of new avenues for the expression of identity. As a "decentralized" religion, Hinduism itself may have harbored seeds of rebellion against caste. For example, the doctrine of bhakti ${ }^{12}$ frees, at least to some degree, the practicing Hindu from the imposition of doctrine imposed by 
the dictates of doctrinal knowledge alone. Fifty years ago, Singer (1958) found that even Brahmins were often joining and even leading the movement toward bhakti (devotional love) even though it was inimical to the religious control long attributed to their caste. And yet, the gradual erosion or blurring of caste lines has let to a contrary trend: that of Sanskritization. As Luce (2007: p. 125) states: "This term describes a trend in which the lower orders are now copying the culture of the upper orders by following the same gods, attending the same temples, and celebrating the same festivals." Interestingly, Marriott's fieldwork, in a study now nearly sixty years old, concluded that the process of Sanskritization has proceeded quite slowly, which he found surprising in a religion and culture so ancient. However, since that time, Sanskritization appears to be proceeding at a pace that is accelerating, and brings with it an interesting contradiction. On one side, Sanskritization was made possible by the legal strictures and social erosion of caste. Without these, it would be impossible for lower castes to mimic the beliefs and behaviors of the higher castes. On the other side, Sanskritization reinforces in some measure the legitimacy of class through imitation. Politically, the lower castes may be acting in the opposite direction ${ }^{13}$, but socially and religiously, their beliefs and practices are becoming more similar. As Luce (2007: p. 125) states: “... attributes, such as dress or dietary habits, have become increasingly general to all castes... If you enter an urban home in today's India, it would be hard to tell the caste of its occupants. The gods depicted in the small household shrine are the same. The people follow the same traditional upper-caste rituals."

A second, more radical shift in Indian religion is that of the neo-Buddhism of BhimraoAmbedkar, who, as Luce (2007: p. 12) accurately states: “... to millions of Indians he is a more important figure than Gandhi." Ambedkar's message to Dalits and to India generally is tightly woven into the cultural fabric of that society. He was a primary author of India's constitution (written in 1950), which provide voting rights for all adult Indians, including the Dalits, who now number over two hundred million ${ }^{14}$. It was Ambedkar'sbelief that only religious conversion could alter the status position of the lowest castes (Koenraad, 2008) since his own conversion in 1956, some six million converts follow the path of neo-Buddhism, and most of these were formerly members of Ambedkar's own Mahar caste and those related to that caste, geographically. There are two striking features related to this religion conversion that may have implications for all Hindus who immigrate. First, this may signal the possibility that Hindus - particularly those who are of lower caste-are willing to leave a religious belief that their families and their social groups have followed, quite possibly, for millennia. Secondly, as Ambedkar and the subsequent converts came, to a large degree, from both educated and urban backgrounds, this may further indicate the possibility for religious change and conversion in the United States, in which Indians share those two characteristics.

\footnotetext{
${ }^{13}$ Luce (2007:125) remarks: “... in the political world, India's lower castes move in the opposite direction from 'Sanskritization'," which many now follow in their children's schooling."

${ }^{14}$ This does not mean, however, that Indians no longer vote independently of their caste interest. Communalism has become such a significant aspect of Indian democracy that the joke: "In India you do not cast your vote, you vote your caste,” retains a high degree of truth.

${ }^{15}$ Of course, this Indian immigrant population is not all Hindu; of the billion Indians, over two hundred count themselves as Muslims, making India the second most populous Muslim nation in the world.
}

\section{Conclusion: Immigration, Identity, and Patterns of Belief}

Indian immigration to the United States tends to be a relatively recent phenomenon. Even though the first south Asians began to arrive in 1820, as Williams (2004: p. 220) remarks, "... but not until the beginning of the twentieth century did more than 275 persons arrive from India in a single decade." With the Immigration Law of 1965, the doors were finally opened to large numbers of Indians, with the stipulation that only those with needed skills would be included, creating an upper-middle to lower-upper class of professionals, including, doctors, engineers, software specialists, scientists and nurses (Gimpel \& Edwards Jr., 1999; Williams, 2004). Families of this selected group were then allowed to immigrate, increasing the population of Asian Indians in the United States to over one million, with a projected rate of growth of over $16 \%$ between 2000 and 2004, establishing it as one of the wealthiest ethnic groups in the United States (2000 Census Bureau: Population Profile) ${ }^{15}$.

Thus, several highly significant indicators suggest that the patterns of religious belief and even affiliation among first- and second-generations Indians in the United States would change radically. These include:

- Geographical distance from the native society.

- A religious belief system that is highly syncretic and accommodating.

- Dynamic changes in the religious fabric in India, including Sanskritization and neo-Buddhism.

- The rise of a highly educated, professional class, indicating a trend toward secularization.

- Entry into a society with an established and increasing history of change in religious belief and affiliation.

- Possessing the language of the new culture.

Moreover, it is likely that there would be a cumulative effect brought on by the presence of all of these factors operating together. Willams (2004) suggests that Hinduism in the United States has followed two separate lines of development. The first he relates to community size and population density. Hinduism practiced smaller groups would tend to be ecumenical in nature, with a common language of English accompanied by a high degree of cultural assimilation. For example, Williams suggests that pregnancy rituals would translate into "baby showers". The second line of development is the length of residence. As immigrants move from the immediate pressures of adapting to new cultural traditions, and achieving a satisfactory measure of social and economic security, they can reinvest time once more in their religious traditions. With time, prosperous American-Indians may even be able to reshape religion in India to some measure, thus completing what he terms the "transnationalism” of religion.

Both these lines of development are predicated on the assumption that Hindus will remain within the sphere of Hindu belief and practice with exposure to a society that is highly dissimilar. In an attempt to answer the question of the stability or "transnationaization" of Indian identiy, Joshi (2006)—in a penetrating set of case studies combined with interviews with second-generation Indians (she defines these as being born between 1979 and 1992) who are the children of immigrants, having been born in the US or having arrived by age six. The second generation experiences a social milieu markedly different from the first generation in the respect that a critical mass of 
Indians may now attend the same schools, live in the community, and being identified by others as less ethnically marginal. Joshi's case study of "Neha" clearly reveals a dramatic shift from the religion of her parents, toward a more secular identity. This may have emerged partly as a realization, in school, that she was more marginalized for her religion than for her ethnicity. When questioned about her identity, Neha responded: "My parents emigrated from India, but I was born here" (Joshi, 2006: p. 167). Consistent with Joshi's findings with other subjects in her case studies, Neha identified two central components to remaining "Indian" in the United States: language and religion. Neha did not speak her native language (Punjabi) and spoke only English with her parents, even at home. She did not identify with Hinduism as a belief system, while she did state that she "believed in God". Joshi concludes that: “... this disconnection from her home religion has developed [into] an alternative worldview in the American civil religion of individualism. She rejects Hinduism and Indian culture as such because they are too "collectivistic" in the philosophical approach... She cannot fit them into a Christian box-the Western, monotheistic norm that defines in her mind that which is worthy. Hinduism [in her view] is unsophisticated by comparison” (Joshi, 2006: p. 169).

Joshi also employs a variety of innovative techniques in her interviews with second-generation immigrants. For example, each respondent is invited to assemble a personal "pie chart" that allows them to identify central components of their identity, but also to indicate the magnitude of that component. She asks them to assemble this chart in terms of their current perceptions, as well as retrospectively; i.e., how do the respondents believe that their identities have changed over time? This is significant: it allows for self-expression of the loss (or recovery) of important components of identity such as religious belief. With specific reference to the role of religion, Joshi (2004: p. 202) asks these questions:

ADOLESCENCE:

- Religiously, how do you identify?

- Where did you (your family) worship?

- Was religion your primary reason for participating in group worship? Was it to preserve tradition? Was it for social reasons? Was it to celebrate home culture? Was it to strengthen local community? Was it for fun? Was it to speak the language?

- How often did you attend religious events?

- Did you attend "Sunday school" classes? If so, for how long? Frequency?

- How well did you understand the rituals and traditions of the religion?

- Were you aware of your caste, jati or nat (for Hindus)? COLLEGE:

- How religious were you? Did you perform individual acts of worship in college?

- How often did you attend religious events? Did you attend "Sunday school" classes?

- Were you more or less religious as a college students compared to as an adolescent?

- What kind of knowledge did you have about your religion? How well did you understand the rituals and traditions of the religion?

- How did you practice your faith?

- What was your main reason for participating in group worship? Was it to preserve tradition? Was it for social reasons?
Was it to celebrate home culture? Was it to strengthen local community? Was it for fun? Was it to speak the language?

- How important was it for you to go to a temple, mosque, church, or gurdwara?

ADULTHOOD:

- Are you still religious? How religious are you?

- Are you more or less religious when you were in college?

- Do you have a shrine at home (for Hindus)?

- How much knowledge do you have about your religion?

- How well do you understand the rituals and traditions of the religion?

- How do you practice your faith? Where do you worship?

- Do you perform individual acts? Or do you participate more in group worship?

- Is religion your primary reason for participating in group worship? Is it to preserve tradition? Is it for social reasons? Is it to celebrate home culture? Is it to strengthen local community? Is it for fun? Is it to speak the language?

- How often do you attend religious events?

- What do you need to retain the religious traditions and rituals?

- How important is it for you to go to a temple or mosque?

- How does belonging to you feel about your Indian identity?

What Joshi discerns from this study does not parallel Weber's (1958) somewhat grim prediction that "the gods are irretrievably fading" and that our identities are haunted with the "ghosts of dead religious beliefs". Joshi finds, in contrast, that the gods and the religion itself are changing, rather than fading. She concludes that “... Indian roots have been planted in American soil, soil tempered with unique cultural norms and saturated with ideations of God. The nutrients and pests of this American soil will bend the roots and shape the trees, creating shapes and forms unlike those found in India or the Indian diasporas of the Caribbean or the United Kingdom" (Joshi, 2006: pp. 13-14). Thus Durkheim's thought, though thoroughly an "organic modernist, finds expression and resonance in a postmodern, national world. As societies mingle, so do the gods, and their forms echo the social milieu into which they are born".

\section{REFERENCES}

Armstrong, K. (2004). The battle for God. New York: Knopf.

Babb, L. A. (2001). Redemptive encounters: Three modern styles in the Hindu tradition. Berkeley: University of California Press.

Bellah, R. (1975). The broken covenant. New York: Seabury Press.

Berger, P. (1967). The sacred canopy. Garden City, NJ: Doubleday and Company.

Brockington, J. (2005). The sanskrit epics. In G. Flood (ed.), The blackwell companionto hinduism (pp. 116-128). Malden, MA: Blackwell Publishing Ltd.

Cladis, M. S. (2001). Introduction to Durkheim's the elementary forms of religious life. New York: Oxford University Press.

Coser, L. (1977). Masters of sociological thought: Ideas in historical and social context (2nd ed.). Long Grove, IL: Waveland Press.

Cox, H. (1971). The Secular City. New York: Macmillan.

Cutler, N. (2005). Tamil hindu literature. In G. Flood (Ed.), The blackwell companion to hinduism (pp. 145-158). Malden, MA: Blackwell Publishing Co.

Dandekar, R. N. (1997). Vedic mythology: A rethinking. In M. Witzel (Ed.), Inside the texts, beyond the texts: New approaches to the study of the Vedas (pp. 39-48). Cambridge, MA: Harvard University Press. Durkheim, E. (1966). The rules of sociological method. New York: 
Free Press.

Durkheim, E. (2001). The elementary forms of religious life. New York: Oxford University Press.

Durkheim, E., \& Marcel, M. (1963). Primitive classification (Trans. Rodney Needham). Chicago: University of Chicago Press.

Evans-Pritchard, E. E.(1960). A selection from nuer religion. In C. Leslie (Ed.), Anthology offolk religion (pp. 53-104). New York: Vintage Books.

Fellows, W. J. (1998). Religions east and west. Orlando, FL: HarcourtBrace.

Ganeri, J. (2005). Hinduism and the proper work of reason. In G. Flood (Ed.), The blackwell companion to hinduism (pp. 411-446). Malden, MA: Blackwell Publishing Co.

Gimpel, J. S., \& Edwards, J. R.(1999). The congressional politics of immigrationreform. Needham Heights, MA: Allyn and Bacon.

Goode, W. J. (1951). Religion among the primitives. New York: The Free Press.

Gorski, P. S. (1998). Historicizing the secularization debate: Church, state and society in late medieval and early modern Europe, ca. 1300 to 1700. American Sociological Review, 65, 138-167.

Griswold, W. (2008). Cultures and societies in a changing world. Thousand Oaks, CA: Pine Forge Press.

Hout, M., \& Fischer, C. (2002). Why more Americans have no religious preference: Politics and generations. American Sociological Review, 67, 165-190.

Joshi, K. Y. (2006). New roots in America's sacred ground: Religion, race, andethnicity in Indian America. Piscataway: Rutgers University Press.

Koenraad Elst Site (2008). Are neo-Buddhists Hindus? http://koenraadelst.bharatvani.org/books/wiah/ch11.htm

Kurtz, L. R. (2007). Gods in the global village. Thousand Oaks, CA: Pine Forge Press.

Lowie, R. H. (1924). Primitive religion. New York: Boni and Liveright.
Luce, E. (2007). In spite of the gods. New York: Doubleday.

MacDonald, D. B. (1905). A selection from the Prolegomma of IbnKhaldun. Leiden: E. J. Brill.

MacKenzie, D. A. (1994). India: Myths and legends. London: Senate Press.

Needham, R. (1963). Introduction to Durkheim's primitive classification. Chicago: University of Chicago Press.

Parsons, T. (1949). The theoretical development of the sociology of religion. Glencoe, IL: The Free Press.

Pew Forum on Religion and Public Life (2008). United States religious landscape survey. http://religions.pewforum.org/reports

Sax, L. J. et al. (2004). The American freshman: national norms for fall 2004. Los Angeles: UCLA Higher Education Research Institute.

Singer, M. (1958). The great tradition of Hinduism in the city of Madras. Journal of American Folklore, 71, 281.

Stark, R., \& Finke, R. (2000). Acts of faith: Explaining the human side ofreligion. Berkeley: University of California Press.

Swanson, G. E. (1960). The birth of the gods. Ann Arbor: University of Michigan Press.

United States Bureau of Census (2000). Population profile: Dynamic version. http://www.census.gov/prod/cen2000

Waghorne, J. P. (2004). Diaspora of the gods. New York: Oxford University Press. doi:10.1093/acprof:oso/9780195156638.001.0001

Weber, M. (1949). The methodology of the social sciences. New York: Free Press.

Williams, R. B. (2004). Williams on South Asian religions and immigration. Burlington, VT: Ashgate.

Witzel, M. (2005). Vedas and upanishads. In G. Flood (Ed.), The blackwell companion to hinduism (pp. 68-98). Malden, MA: Blackwell Publishing Ltd.

Wuthnow, R. (1998). Afterheaven. Berkeley: University of California Press. 